\title{
Naturalist, historiker, moder: Mathilda Mallings paratextuella strategier
}

\begin{abstract}
Naturalist, historian, mother: Mathilda Malling's paratextual strategies

During the more than forty years of her career, Mathilda Malling (18641942) wrote books for children and adults as well as texts in different genres. Her oeuvre provides an example of the strategies used by female authors to achieve publication in a male-dominated literary field, as well as how the critics reacted when women transgressed the boundaries of what was acceptable in terms of style and subject matter. Through an analysis of Malling's paratextual strategies and choice of narrative situation, this article aims to show how ideas about gender, genre and authority produced differing restrictions and opportunities for authors when writing for children and adults. Both in her paratexts and in her choice of narrator, Malling played with various notions about the author, using them to stage different artistic identities such as naturalist, historian or mother. In the prefaces of her adult novels, she authorized her narratives through references to claims about the truth, objectivity and an expert's knowledge. The preface to her book for young readers, in contrast, highlighted everyday life, the author as a member of a family, and children. Her tone of voice was affectionate and light, and far less serious than when she was prefacing adult literature. This aesthetics of the quotidian and of intimacy was further staged in her children's literature in terms of the situation of the narrator.
\end{abstract}

Barnlitteraturens relation till vuxenlitteraturen är en fråga som har debatterats kontinuerligt i Sverige sedan den moderna barnlitteraturforskningens födelse under 1960-talet. Under denna period har det skett en fokusförskjutning i förhållningssättet till den barnlitterära texten och som Boel Westin har formulerat det har forskningen gått från att vara normativ till att bli diskursiv. Medan den tidiga barnlitteraturforskningen ofta försökte fastställa vilka kriterier som gjorde en text till en barnbok och därigenom formulera en barnlitteraturens egenart, har den nyare forskningen snarare intresserat sig för de litterära strategier som utvecklats i den barnlitterära traditionen (Westin 1998, 134). Genom att betrakta barn- och vuxenlitteraturen som diskursiva praktiker snarare än stabila kategorier kan 
man synliggöra ett mer dynamiskt samspel mellan litteraturarterna. Samtidigt skapar det möjligheter att vidga diskussionen till att inkludera frågor om hur exempelvis föreställningar om genrer, kön och författare har påverkat utformningen av enskilda verk.

I följande artikel kommer jag att diskutera hur barn- och vuxenlitteraturen respektive olika genrer skapade skilda uttrycksmöjligheter för författare i det sena 1800-talet, men också hur utsägelsevillkoren kan relateras till kön. ${ }^{1}$ Via en analys av Mathilda Mallings (1864-1942) paratexter och berättarstrategier vill jag visa hur hon går i dialog med såväl samtidens föreställningar om kvinnliga och manliga författare som olika idéer om barn- och vuxenlitteratur. Min diskussion baseras på en genomgång av hela författarskapet, men i analysen kommer jag huvudsakligen att utgå från några belysande exempel.

Termen paratext har lanserats av Gérard Genette och används för att beteckna dels delar av den fysiska boken, som titlar, pseudonymer och bokomslag, dels utanförliggande företeelser som kan påverka läsningen av verket. Det kan röra sig om recensioner, intervjuer eller biografisk information om författaren (Genette 1987/1997, 4f). Paratexterna befinner sig på en glidande skala mellan fiktion och ickefiktion och deras position "på tröskeln" mellan verk och omvärld har gjort att de ofta fungerat som ett slags förhandlingsrum. Genom paratexterna har författare bland annat kunnat ge antydningar om hur romantexten ska tolkas och föregripa väntad kritik, men de har även utnyttjats för att bygga upp auktoritet eller iscensätta en konstnärlig identitet (Genette 1987/1997, 196-236). Inte minst de kvinnliga författarna använde under 1800-talet paratexterna för att överbrygga klyftan mellan den privata, kvinnliga sfären och en manlig offentlighet, och således hantera de motsägelsefulla krav som ställdes på dem i ett litterärt klimat där mannen utgjorde normen (Arping 2002, 34-37 och 115-144).

Mallings brokiga författarskap illustrerar osedvanligt tydligt några av de paratextuella strategier som kvinnliga författare kunde utnyttja för att bli publicerade, men även hur kritikerna kunde reagera när kvinnorna överskred uppfattningarna om hur en kvinna borde skriva. I såväl paratexterna som valet av berättare spelar Malling med olika föreställningar om författare och framför allt förorden ger en uppfattning om hur hon ville framställa sig för den litterära publiken. Samtidigt utgör de en indikation på vilken sorts egenskaper som betraktades som auktoritetsskapande i förhållande till olika slags texter och beroende på vilken genre hon var verksam inom skapade hon författarsubjektet som till exempel naturalist, historiker 
och moder. Mer generellt använde sig Malling även av olika strategier i barn- och vuxenlitteraturens paratexter. Medan de vuxenlitterära företalen betonade kunskap, intellektualism och objektivitet, auktoriserades barnlitteraturen genom en förankring i hem- och familjeliv.

\section{Från naturalist till historiker}

Mallings förvandling från en av det moderna genombrottets mest kontroversiella författare till den "svenska missromanens grand old dame" (Frenckell 1934, 122) har förundrat både samtiden och senare forskning, och författarskapets utveckling och omtolkningar har bland annat diskuterats i Birgitta Neys avhandling Bortom berättelserna: Stella Kleve -Mathilda Malling (1993). Malling debuterade 1884 med "Flirtations" under pseudonymen Stella Kleve och väckte under 1880-talet skandal med sina dekadent färgade gestaltningar av kvinnlig sexualitet. I slutet av decenniet tystnade hon, för att 1894 återkomma till den litterära scenen med den anonymt publicerade En roman om förste konsuln: från den 18 Brumaire till freden $i$ Amiens, som till skillnad från Kleve-alstren fick fin kritik. Med En roman om förste konsuln började en ny period i författarskapet och under namnet Mathilda Malling utgav hon därefter närmare trettio romaner, varav den sista publicerades 1931. Den nya eran markerades av namnbytet från Kleve till Malling, nya genrer och en annorlunda litterär estetik. Även i det senare författarskapet behandlade Malling kvinnors kärlek och sinnlighet, men huvudsakligen i den historiska romanens och herrgårdsberättelsens form. Hon publicerade också en barnbok, Det hvita huset och den röda stugan: sagor och historier (1911).

Under 1800-talet var förord ofta ett debutfenomen (Arping 2002, 131) och det var framför allt i inledningen av författarskapet eller när hon började skriva i nya genrer som Malling använde förord. De återfinns i Kleve-periodens naturalistiska texter, de historiska romanerna och i barnboken. Genomgående i författarskapet inriktades paratexterna på att auktorisera såväl författaren som den efterföljande texten, men Malling utnyttjade olika litterära medel för att uppnå detta.

Till debuten "Flirtations" och den första romanen Berta Funcke: berättelse (1885) skrev Malling inte själv förord utan försökte stärka sin position genom att be den danske dekadansförfattaren Herman Bang skriva introduktioner. Att låta en mer etablerad författare skriva förord till en debutant var ett vanligt fenomen (Heggestad 1991, 54) och valet av Bang är signifikativt för den litterära inriktning som Malling önskade verka inom. Hon ville vara modern och drogs till de nya litterära strömningarna, som dekadans och naturalism (Malling 1902, 181f). 
I det egna förordet till Alice Brandt: en kvinnoprofil (1888) betonar Malling sitt samröre med dessa traditioner via motton och företalet. Hon associerar sin berättelse med naturalismen genom att framställa romanen som en fallstudie: "Då jag kallar denna min andra bok "Alice Brandt", liksom jag kallade den första "Berta Funcke", är det för att än en gång betona / ... / att det är blott individen, alldeles inte typen, som jag vill skildra." (Malling 1888) Det är det specifika fallet och dess egenheter som intresserar henne, inte några idealtyper eller allmänna tendenser. Förordet är skrivet i en defensiv ton och Malling försöker föregripa kritik om osedlighet genom att betona att hennes litterära gestaltningar av unga kvinnor baseras på omfattande studier av omgivningen. I likhet med den naturalistiska författaren med vetenskapsmannens krav på objektivitet och observationer, framställs författarsubjektet i Alice Brandt som en iakttagare av samtiden. Innehållet i romanen underbyggs därmed i förordet genom skapandet av ett auktoritativt författarsubjekt som påstås ha stor kännedom om det behandlade ämnet. Författarens kunskap och intellektualism understryks vidare genom infogandet av citat, mestadels på originalspråk, från Thomas Moore, bröderna Goncourt, La Bruyère och Gustave Flaubert. De skönlitterära mottona från de två första författarna förebådar samtidigt den efterföljande berättelsens fokus på kvinnor och erotik, och i synnerhet referensen till de franska bröderna Goncourt implicerar ännu en gång en naturalistisk berättarhållning och en dekadent estetik.

Paratexterna till Mallings första historiska roman, En roman om förste konsuln, är av en annan karaktär och de producerar en föreställning om författaren som historiker snarare än som vetenskapsman. Mottona på försättsblad och i början av varje kapitel är huvudsakligen hämtade ur brev och andra historiska källor, och efterordet till romanen redovisar den historiska bakgrunden till handlingen. En roman om förste konsuln skildrar en dramatisk period i Napoleons liv och i likhet med majoriteten av Mallings historiska romaner kretsar berättelsen runt en känd person eller ett omskrivet historiskt skeende. Det innebär höga krav på historisk tillförlitlighet, eftersom många läsare kommer att ha förkunskaper som den litterära skildringen ställs mot. För- och efterorden till hennes historiska romaner består följdriktigt till största delen av redogörelser för det historiska källäget samt ordförklaringar och biografiska uppgifter om karaktärerna.

I En roman om förste konsuln är det den senare aspekten som påstås ha motiverat efterordet. Författaren säger sig ha uppmärksammats på att alla läsare kanske inte känner till vilka de mindre kända personerna i berättelsen är. Efterordet tillhandahåller en lista med kortfat- 
tade beskrivningar över dessa, en släkttavla och "ett par observanda angående kulturhistoriska och historiska fakta, som kunnat antagas ej vara allmänt bekanta" (Malling 1894, 221). Därmed anammar författaren en expertposition i förhållande till läsaren och delar med sig av sin större kunskap. Valet att ordna informationen kapitelvis och i punktform i efterordet, snarare än i en löpande, berättande text, konnoterar dessutom en akademisk tradition. Fastän förmedlingen av data i efterordet framställs som en tjänst mot läsaren, får det samtidigt funktionen att skapa en bild av författaren som bildad och beläst. Romanen antyds ha skrivits av en person med stora kunskaper om Napoleontiden och även om texten uppenbarligen är en fiktiv berättelse, garanteras dess autencitet vad gäller tidsdetaljer och historiska fakta.

\section{Intimitetens estetik}

Oavsett genre auktoriseras Mallings vuxenböcker genom hänvisningar till sanningsanspråk och författarens kunskap. Inte i något av dessa företal synliggörs författaren som privatperson och trots det känsloladdade försvaret av romanen i förordet till Alice Brandt är framställningen relativt opersonlig. Företalet i hennes barnbok framhäver däremot $i$ högre grad vardagen, familjemänniskan och barnet. I introduktionen till Mallings samling med berättelser för barn, Det hvita huset och den röda stugan, beskrivs författarsubjektet som mor och författarverksamheten placeras i en intim familjekrets:

Hvar gång jag håller på med en ny bok, komma barnen och fråga hvad den skall heta och om de få läsa den. "Nej, det få ni nog inte - det är bara en bok för stora människor, inte alls någon riktigt 'rolig bok'. - "Hvarför skrifver mor aldrig en bok för oss?" - "Det skall jag göra, när jag blir färdig med den här." - "Det har du nu sagt så många gånger, och det blir aldrig af." Men här kunna ni själfva se, att det verkligen - sent omsider - har blifvit af! (Malling 1911)

Skrivandet av boken rättfärdigas genom referenser till barnens önskemål och den framställs som en gåva till de egna barnen. Förtalet anslår ett personligt och lättsamt tonfall fjärran från de vuxenlitterära företalens allvarsamhet. I stället skapas en stämning av närhet och kärvänlighet, och denna vardagens och intimitetens estetik iscensätts även genom texternas berättarsituationer.

Företalet till Det hoita huset och den röda stugan anknyter till en föreställning om den berättande modern, som var framträdande i sekel- 
skiftets barnlitteratur. Att framställa föräldrar eller andra personer i barnens närhet som författare till eller berättare i barntexter utgjorde en gammal tradition. Den berättande mormodern eller amman var vanligt förekommande inom sagogenren (Rossholm 1974, 160-166) och i de didaktiska föräldraråden figurerade föräldrar som författarsubjekt. Runt sekelskiftet 1900 var det emellertid modern som framför allt kom att associeras med barnens litteraturupplevelser (Furuland 1988, 57). I paratexterna betonades moderns betydelse för högläsningen genom titlar som Ottilia Adelborgs Barnens julbok för mamma och småttingarna (1885) och Mathilda Langlets Mamma, tala om något roligt! (1895), och modern som läser för sina barn avbildades gärna på bilderbokens framsidor och i illustrationer (Hallberg 1985, 11-15). Precis som i konstruktionen av författarsubjekt till vuxenböckerna anpassades bilden av författaren till Det hvita huset och den röda stugan till den texttyp som följde förordet och $\mathrm{i}$ anammandet av den berättande modern anslöt sig Malling till vad som närmast var en konvention i sekelskiftets barnlitteratur.

Kvinnans starka position inom barnlitteraturen framkommer i Det hvita huset och den röda stugan genom att även berättaren antyds vara mor. Den inledande berättelsen "Det hvita huset och den röda stugan" fungerar som ett slags ram till samlingens sagor och historier, och beskriver flickorna Lettys och Majas vardagsliv i staden respektive sommarstugan på landet. Det är i den senare miljön som flera av de efterföljande historierna utspelar sig och det är ett landskap som närmast är besjälat av moderns minnen och skrönor. De olika platserna introduceras via händelser som mor upplevt eller hört talas om. Texten berättar bland annat om hur mor brukar "visa Letty och Maja alla de ställen, där hon som barn brukade leka med sina syskon och kusiner" (Malling 1911, 15), om människor som "mor [kan] minnas" (Malling 1911,17) och Brudbacken, där mor brukade spana efter bruden som rövats bort av ett troll. Omgivningarna och människorna som bebor dem kommer till liv via moderns upplevelser.

Majoriteten av texterna i Det hvita huset och den röda stugan förankras på ett likartat sätt i specifika föremål eller platser och spinner vilda historier runt dem, och Letty och Maja är i några fall delaktiga i handlingen. Berättelserna kretsar bland annat runt en termometer, en höna och en schackdrottning och den inskrivna berättarsituation poängterar att texterna förmedlas av någon som finns i flickornas närhet. "Den gamla termometern" inleds exempelvis: "Inne under den stora spegeln i förmaket står en rund silfverrofva på järnfot, som ni alltid, när ni voro mindre, kallade 'den lilla klockan'. Men det är visst ingen klocka. Nu ska ni riktigt få höra, hvad det är för en ting- 
est." (Malling 1911, 27) Berättarsituation med en mor som hittar på sagor om sina döttrars vardag är aldrig explicit skildrad, men impliceras av förordet, den inledande novellen och berättarens kommentarer i de övriga. Det krävs exempelvis inte särskilt mycket fantasi för att läsa "De förvandlade pappersdockorna", där Majas kvarglömda pappersdockor blir levande och löper amok, som ett slags humoristisk varningssaga inspirerad av att dottern ännu en gång glömt att städa undan sina pappersdockor. Slutraderna förkunnar även att Maja aldrig mer kommer att låta sina pappersdockor "få glömmas på mattan eller falla i händerna på en klåfingrig fé" (Malling 1911, 86). På så vis fungerar vardagen som ram till de fantastiska historierna och dessa antyds vara sprungna ur den innerliga samvaron mellan förälder och barn.

Förordet till Det hvita huset och den röda stugan innehåller en lättsamhet som inte finns i Mallings vuxenlitterära företal. Strävan efter objektivitet som karakteriserar paratexterna till Alice Brandt och En roman om förste konsuln, respektive det personliga tilltalet i förordet till barnboken, avspeglas också i berättarhållningen. Medan Mallings vuxenromaner har osynliga, opersonliga berättare, präglas barntexterna av en närvarande berättare som emellanåt tilltalar narraten direkt. I Det hvita huset och den röda stugan finns dessutom en lekfullhet och humor som Malling sällan visar i vuxenlitteraturen. Hon både leker med barnlitterära konventioner och en belärande attityd, som i "De förvandlade pappersdockorna", där berättaren framför en lista över olika sammanträffanden, som gör att pappersdockorna får liv:

Märk, att det var för hundrade gången ön var färdigritad! Märk, att det var en torsdagsmiddag klockan 12! Märk, att en mycket mäktig fé, som hade sofvit jämnt hundra år, precis den dagen hade vaknat och var ute och spatserade i sjumilastöflar öfver jordklotet och just gick och undrade, om det fanns något, som hon kunde förtrolla. (Malling 1911, 73)

Den närvarande och lekfulla berättaren utgör ytterligare en aspekt av den vardagens och intimitetens estetik som karakteriserar det barnlitterära företalet hos Malling.

\section{Genre, kön och auktoritet}

I förordet till Alice Brandt respektive efterordet till En roman om förste konsuln framställs författaren på olika sätt som en auktoritet på det behandlade området. Det barnlitterära företalet är mer prestigelöst 
och i stället för att hänvisa till yttre kunskapskällor för att underbygga texten, förankras den i författarsubjektets hemliv. Genom de paratextuella strategierna skapas olika föreställningar om författaren, som kan relateras till såväl Mallings status som författare vid publiceringen som mer allmänna föreställningar om genre, kön och auktoritet. Medan hon i företalet till barnboken inordnade sig i den föregivet kvinnliga familjesfären, inträdde hon i Alice Brandt och En roman om förste konsuln på traditionellt manliga litterära områden. Det kom att prägla såväl Mallings strategier som bemötandet av hennes texter.

Mot slutet av 1800-talet hade det blivit relativt accepterat för kvinnor att ägna sig åt skrivande, men det fanns olika begränsningar för hur kvinnor och män kunde uttrycka sig i litteraturen samt vilka ämnen de kunde diskutera (Englund och Kåreland 2008, 102f). Det fanns i synnerhet skillnader i vad de tilläts tala om med auktoritet. Susan Lanser menar att det finns en parallell mellan en persons möjligheter att göra sin röst hörd i offentligheten och uppvisandet av auktoritet i litteraturen. Hon diskuterar framför allt förekomsten av öppen auktoritet och med det avser hon bland annat förord, explicta referenser till berättarakten och kommentarer riktade till en offentlig narrat. Lanser understryker könets betydelse för hur en författare eller berättare kan uttrycka sig i litteraturen, och i sin undersökning relaterar hon förekomsten av öppen auktoritet både till kvinnans ställning i samhället och allmänna litterära trender. Kvinnans begränsade möjligheter att tala med auktoritet i den offentliga debatten innebar även en inskränkning av den kvinnliga författarens uttrycksmöjligheter: "In cultures such as the ones I am examining, where women's access to public discourse has been curtailed, it has been one thing for women simply to tell stories and another for their narrators to set themselves forth as authorities." (Lanser 1992,18) Att som kvinna fatta pennan och publicera berättelser var en sak, men att framställa författarsubjektet eller en kvinnlig berättare som en auktoritet var en annan.

Medan Malling i det barnlitterära förordet anknöt till en etablerad kvinnlig författarroll, kan de auktoritetspositioner hon intog i paratexterna till Alice Brandt och En roman om förste konsuln sägas vara manligt kodade. Dekadansen, naturalismen och den historiska romanen var litterära inriktningar som under 1800-talet främst dominerades av män (Ney 1993, 161-164 och Hook 1972, 10). Medan dekadansen var problematisk för kvinnan på grund av de större sedliga kraven som ställdes på henne, implicerade den naturalistiska respektive historiska romanen ett manligt författarsubjekt genom 
sina kopplingar till vetenskapsmannen och historikern. Dessa yrken hade starkt manliga konnotationer, då de förutsatte en bildning som var svåruppnåelig för kvinnan i det sena 1800-talet, samt associerades med vad som betraktades som manliga egenskaper som rationalitet, objektivitet och intellektualism.

Associationen mellan texttyp och kön innebar inte att kvinnorna per automatik var förhindrade att skriva i dessa genrer, men att de kunde behöva forma ett författarsubjekt som kombinerade genrens krav med borgerlighetens föreställningar om kvinnan. Pil Dahlerup menar att flera av de kvinnliga åttitalsförfattarna, som Amalie Skram och Victoria Benedictsson, drogs till naturalismen på grund av dess mål att avslöja sanningen om samhällsförhållandena. Hon påpekar att kvinnorna visserligen saknade de kunskaper om de nya naturvetenskaperna som var en av grundförutsättningarna för naturalismen, men att de i stället inom hemmets väggar skolat förmågor som hjälpte dem att uppfylla andra av naturalismens huvudpunkter: "den præcise iagttagelsesevne, den sikre detaljkundskab, den intense indlevelse, den tydelige erindring om de nære dagligdagse hændelser"(Dahlerup 1975, 33). Som Dahlerup beskriver lyckades dessa författare hantera balansgången mellan naturalismens krav och en borgerlig kvinnosyn.

Mallings förord härledde på ett likartat sätt innehållet i Alice Brandt till författarens iakttagelseförmåga, men denna förenades med ett självsäkert tonfall och ett närmast koketterande med litterära referenser. Det finns ett anslag av intellektualism i företalet som i kombination med romanens innehåll tycks ha varit högst provocerande. Varken i denna eller andra texter under Kleve-perioden bad Malling om ursäkt för sig själv och hennes konstnärliga anspråk doldes inte heller bakom någon klädsam kvinnlig blygsamhet. Det faktum att berättelserna hade skrivits av en ung, ogift kvinna gjorde dem ännu mer stötande, eller som signaturen S-e uttryckte det $\mathrm{i}$ en recension av Berta Funcke: "Och denna bok säges vara skrifven af en tjuguårig svensk flicka! Så mycket pinsammare blir totalintrycket." (S-e 1885, 416) Författarens kön påverkade utan tvekan mottagandet av boken. Kanske var det därför Malling valde att inte bara publicera En roman om förste konsuln anonymt, utan också använda pronomenet "han" för att beteckna författaren i efterordet. Kvinnliga författares anammande av en manlig pseudonym under 1800-talet har vanligtvis förklarats utifrån en önskan om att skydda sin identitet eller att få ett mer förutsättningslöst bemötande av kritiken (t.ex. Nordin Hennel 1984, 21), men Mallings val kan också ha att göra med den historiska romanens mansdominerade tradition under 1800-talet. Som 
man kunde Malling skriva och tala med en större självklarhet inom genren, och utan att den inskrivne författarens trovärdighet underminerades av den biografiska författarens kön.

De paratextuella strategierna satte i samma slag både textens och författarens auktoritet i spel. Genom paratexterna kunde olika föreställningar om kön, författare och litteratur jämkas mot varandra, men auktoriseringsförsöken kunde också slå fel och snarast göra kritikerna än mer fientligt inställda. När exempelvis Oscar Levertin recenserade Mallings historiska roman om Rousseau, Eremitage-idyllen: interiörer från 1750-talet (1896), var det med illa dold motvilja mot hennes överloppsgärning. Recensionen inriktades på det huvudlösa i valet av ett så storslaget och närmast uttömt ämne, och innehöll raljerande anmärkningar om Mallings bristande kännedom om eller felaktiga tolkning av de historiska källorna i både stort och smått:

Det hedrar fru Mallings öga, att hon sett de båda männen i sitt rätta plan, liksom hon också väl förstått m:me d'Epinay (men inom parentes hvarför uppgifva hennes födelseår orätt - hon föddes 11 mars 1726, dopattesten finnes i Perrey et Maugras La Jeunesse de m:me d'Epinay). Ganska lyckad är också m:me d'Houdetot; ett sådant uttryck som att hon tjusade genom en sorts "fysisk originalitet" är fint och träffande, medan hennes älskare utan fråga blifvit idealiserad till en tråkig, erotisk söndagshjälte. Författarinnan uppräknar i sitt företal de samtida omdömen, hon funnit om dem båda. När man ej sett sig bättre ikring, gör denna ansats till boksynthet närmast ett löjligt intryck. Det vimlar af notiser om dem. (Levertin 1897, 75f)

I recensionen ställs genomgående recensentens kunskaper mot författarens. På punkt efter punkt försöker Levertin underminera Mallings myndighet och han växlar mellan nedlåtande välvilja och överlägsna korrigeringar. Levertin tycks ha blivit mer provocerad av den kvinnliga författarens ansats och paratextuella strategier än romanen i sig.

Trots spelet med olika författarsubjekt försökte Malling sällan dölja sitt kön. En roman om förste konsuln utgör det enda tillfället då hon anammade ett manligt alias. Intressant nog försökte hon vanligtvis inte heller framhäva sin kvinnlighet som en auktoritetsskapande egenskap. I Bangs introduktion till "Flirtations" antyds en dylik möjlighet, när han beskriver henne som en av samtidens kvinnliga författare som bär bud från ett främmande och hemlighetsfullt kvinnoland: 
Syntes mig, thi for hver Dag forekommer det mig mer og mer, som om de skrivende Kvinder bringe os Bud fra Fjerne og fremmede Lande, som vi vel for have set afbildede paa skjønne Lærreder af store Mestre, men som vi aldrig selv besøgte; vi maa derfor stole paa deres Sanddruhed, som fortæller os om Landet, vi ikke kender. (Bang 1884, cit. i Ney 1993, 27)

Enligt Bang har de kvinnliga författarna ett eget perspektiv på tillvaron och det ger ett speciellt värde till deras skildringar. Malling valde dock aldrig att själv poängtera denna aspekt i de vuxenlitterära paratexterna. I företalet till Alice Brandt framställde hon visserligen författarsubjektet som en betraktare av kvinnor, men inte som en kvinnlig betraktare. Den enda gången hon uttryckligen betonade sin kvinnlighet var i förordet till sin barnbok. Därmed impliceras att kvinnokönet $i$ högre grad betraktades som en egenskap som gav auktoritet i sekelskiftets barnlitteratur.

\section{Slutord}

Paratexternas funktion som ett förhandlingsrum är tydlig i Mallings författarskap. Genom olika författarnamn, motton och förord skapade hon skilda konstnärliga identiteter, men i hennes och kritikernas förhandlingar om författarskapets värde och natur ställdes samtidigt föreställningar om kön, texttyper och auktoritet mot varandra. I Mallings författarskap finns en markant skillnad mellan hennes barnbok och romanerna för vuxna. Samtidigt visar de olika variationerna inom litteraturarterna på vanskligheten i att försöka fastställa en barn- respektive vuxenlitteraturens egenart eller essens. Som jag har försökt visa i mina analyser kunde barn- och vuxenlitteraturen innebära olika möjligheter för sekelskiftets författare, men dessa tog sig även skilda uttryck beroende på exempelvis författarens kön och sociala ställning samt de specifika texternas ämne eller genretillhörighet.

Biographical information: Maria Andersson is writing her doctoral thesis on Swedish female writers in the turn of the century 1800/1900 from a crosswriting perspective. The department of literature and history of ideas at the Stockholm university, Sweden.

Contact:maria.andersson@littvet.su.se 


\section{Bibliografi}

Arping, Åsa. Den anspråksfulla blygsamheten: auktoritet och genus i 1830-talets svenska romandebatt. Diss., Göteborgs universitet. Stockholm/Stehag: Symposion, 2002.

Bang, Herman. "En debut" (1884). Cit. i Birgitta Ney. Bortom berättelserna: Stella Kleve - Mathilda Malling. Diss., Stockholms universitet. Stockholm/ Stehag: Symposion Graduale, 1993.

Dahlerup, Pil. "Den kvindelige naturalist". Vinduet 29 (1975) 2: 30-37.

Englund, Boel och Kåreland, Lena. Rätten till ordet: en kollektivbiografi över skrivande Stockholmskvinnor 1880-1920. Stockholm: Carlsson, 2008.

Frenckell, Ester von. "Mathilda Malling: Den svenska missromanens grand old dame, som från litteraturspalten åkt in bland familjenotiserna". Astra 16 (1934) 6: 122-126.

Furuland, Lars. "'Anrättningar af andlig barnaspis': om barnbokskritikens bildspråk". I Böcker ska blänka som solar: en bok till Vivi Edström. Red. Boel Westin. Stockholm: Rabén \& Sjögren, 1988, s. 48-60.

Genette, Gérard. Paratexts: thresholds of interpretation (1987). Övers. Jane E. Lewin. Cambridge: Cambridge UP, 1997.

Hallberg, Kristin. "Bilderbokens barn - drömmens och verklighetens resenärer: svenska bilderböcker 1880-1945". I I bilderbokens värld 1880-1980. Red. Kristin Hallberg och Boel Westin. Stockholm: Liber förlag, 1985, s. $11-54$

Heggestad, Eva. Fången och fri: 1880-talets kvinnliga författare om hemmet, yrkeslivet och konstnärskapet. Diss., Uppsala universitet. Uppsala: Avdelningen för litteratursociologi vid Litteraturvetenskapliga institutionen, Uppsala universitet, 1991.

Hook, Andrew. "Introduction". I Sir Walter Scott, Waverly (1814). Harmondsworth: Penguin Books, 1972.

Lanser, Susan S. Fictions of authority: women writers and narrative voice. Ithaca: Cornell UP, 1992.

Levertin, Oscar. "Eremitageidyllen: interiörer från 1750-talet af Mathilda Malling". Nordisk tidskrift för vetenskap, konst och industri 20 (1897) 1: 71-77.

[Malling, Mathilda], Stella Kleve. Alice Brandt: en kvinnoprofil. Helsingborg: Österling, 1888.

[Malling, Mathilda]. En roman om förste konsuln: Från den 18 Brumaire till freden i Amiens. Köpenhamn: Bojesen, 1894.

Malling, Mathilda. "Min första bok". I När vi började: ungdomsminnen af svenska författare. Stockholm: Ljus, 1902, s. 180-193.

Malling, Mathilda. Det hvita huset och den röda stugan: sagor och historier. Stockholm: Bonnier, 1911.

Ney, Birgitta. Bortom berättelserna: Stella Kleve - Mathilda Malling. Diss., Stockholms universitet. Stockholm/Stehag: Symposion Graduale, 1993. 
Nordin Hennel, Ingeborg. "Ämnar kanske fröken publicera något?" kvinnligt och manligt i 1880-talets novellistik. Stockholm: Almqvist \& Wiksell, 1984.

Rossholm, Margaretha. Sagan i nordisk sekelskifteskonst: en motivhistorisk och ideologisk undersökning. Diss., Stockholms universitet. Stockholm, 1974.

S-e. Recension av Ernst Ahlgrens Pengar och Stella Kleves Berta Funcke. Ny svensk tidskrift 6 (1885) augusti: 408-418.

Westin, Boel. "Vad är barnlitteraturforskning?" I Litteraturvetenskap: en inledning, red. Staffan Bergsten, Lund: Studentlitteratur, 1998, s. 125-137.

Keywords: Mathilda Malling, paratexts, gender, crosswriting

1 Jag kommer i artikeln att göra skillnad på litteraturarter och genrer. Med litteraturart avser jag barn- och vuxenlitteratur, d.v.s. två relativt vaga och övergripande textkategorier som definieras av sin avsedda målgrupp. Jag betraktar genrer, t.ex. historisk roman eller saga, som underkategorier till litteraturarter och dessa definieras i högre grad av gemensamma textuella element som motiv, form etc. 